\title{
CARLA MARCATO
}

\author{
'SLEEP' - 'DREAM' - 'VISION': SOME SIGNIFIERS AND \\ DESIGNATA IN LATIN AND THE ROMANCE LANGUAGES
}

\section{Introduction}

Sleep and one of the most significant aspects of sleep, dream, not to mention vision-that which is generally but not always seen in a dream while sleeping, and which can, therefore, be the same as dream-are phenomena that influence human history, and around which myths, legends and symbols have been created. The importance attributed to dream and vision derives from the fact that they allow man contact with the supernatural, the mysterious, the fantastic. Oneiromancy, or the art of interpreting dreams, is the subject of full-fledged treatises, and in each case it offers various interpretive keys for dreams, keys for distinguishing true dreams from false or bad dreams (i.e. the incubus), or for recognizing the possibility that a dream may or may not reveal the future. As far as sleep goes, it is its similarity with the state of death and the alternation between sleep and wakefulness - similar to the one between night and day-that grants it a space all its own in religion and myth. In Greek mythology, Sleep, the son of Erebus and of Night, is the twin brother of Thanatos, death.

The phenomenology of sleep, and the psychic activities connected to it, is highly complex; it involves not only science, but also religion, philosophy, literature, and art.

If sleep, leaving aside its varied features, is a situation easily understood and definable for everyone, this is not the case for that which we see either in sleep or in states that are in some way similar if not equal to wakefulness-one need only think of the expression 'daydreaming' or, in Italian, 'sognare ad occhi aperti' (to dream with one's eyes open). ${ }^{1}$ The difficulty in classifying through words situations that imply different experiences, ones which do not fall within the coordinates of time and space, is also reflected in the lexical repertory relating to such experiences. Words that overlap formally are charged with semantic density, and their meanings are so enriched by metaphor that they present themselves to us with highly nuanced contours, and a rich vocabulary of synonyms ensues. 
Dream is not only the psychic activity that occurs during sleep; it is also the content of a dream, or the images that populate dream. But dream is also an assembly of figural meanings: a fantastic imagination, a condition of particular well-being or happiness. A dream can also be called a vision; dream and vision can coincide as phenomena, and the words which designate them can be synonyms. But this is not always the case, for, contrary to dream, vision can be considered a truthful apparition. Moreover, vision is also hallucination, ecstasy, and spiritual contemplation. ${ }^{2}$ It can also be induced with specific techniques, and has a particular meaning for the history of religion; in some religions it can also mean direct contact with the divine. Exceptional visions can also be the objects of literary works, ones that consist essentially in the retelling of a dream-vision (hence so-called 'visionary literature'). Visions which are objects of literary works

consistono nell'affacciarsi, alla esperienza del soggetto (autore, personaggio di un dialogo o di un racconto), di una realtà sovrasensibile (di solito l'oltretomba) e comunque inaccessibile ai modi usuali di conoscenza (futuro terreno personale, proprio o altrui; escatologia individuale o collettiva) e, conformemente a ciò, l'esposizione delle circostanze entro le quali le visioni si attuano comprende di norma, per il protagonista, una sospensione dello stato di coscienza vigile: il sogno o una vera e propria cesura improvvisa (catalessi o altri modi di morte apparente) o l'estasi in tutta la sua ganmma di modalità. ${ }^{3}$

(consist of the appearance, in the experience of the subject [the author or the character in a dialogue or a narrative], of a supersensory reality [usually the afterlife] in any case inaccessible to the usual modes of knowing [one's own personal, earthly future or someone else's; individual or collective escatology], and, in conformity with this, the exposition of the circumstances within which visions occur involves, as a rule, for the protagonist a suspension of the state of vigilant consciousness: dream, or a veritable sudden caesura [catalepsy or other modes of apparent death], or ecstasy in the full range of its modalities.)

In visionary literature, in particular of the Latin-Christian tradition centred on a vision of the beyond, vision is often connected to states of apparent death, to situations of grave infirmity: "ex profunda mortis quiete" (from the deep quiet of death), "admirandas visiones de illo redivivo" (the wonderful visions of that resurrected one); vision can also be rendered with a formula, as in the following attestation: "[mulier] que in extasi rapta" (a woman who was rapt in ecstasy) which continues with "rediens multa ac miranda narravit" (when she returned told of many wondrous things), in which the participle rediens "caratterizza il testo come resocon- 
to di un 'viaggio' nell'aldilà" (Ciccarese 224, 342, 394) (characterizes the text as an account of a 'voyage' to the beyond).

Whoever wishes to map out the Italian and, more generally, the Romance lexical terrain pertaining to the concepts of sleep, dream, and vision, runs the risk of ending up with a confusion of words. Each of these words often intersects with the others, and not only on a formal level, but, especially, on a semantic one; the determination of a taxonomy is thus extremely problematic. Hence the necessity to make a selection of the lexical material available and to choose a perspective from which to initiate the analysis. We will move ahead, therefore, from the words sonno, sogno, visione (sleep, dream, vision) as used in Italian, reserving for them a larger space within the scope of the Romance languages. ${ }^{4}$ We will also make reference especially to early documentation that appears more considerable in terms of both its formal variants and meaning. It should be observed, meantime, that in Italian visione (vision), as opposed to sogno (dream), is a word belonging to the cultured and literary traditions, and, moreover, that in old Italian sonno (sleep) can also be used to indicate sogno (dream). We will consider, then, the Latin situation, pausing in particular on the terms somnus, somnium, visio (the origin for the Italian somno, sogno, visione) and their evolution in the Romance languages. The reconstruction of meanings and signifiers from Latin to the Romance languages - a task which proves complex because of the difficulty in tracing clear boundaries between phenomena such as dream and vision-takes into account not only what has been lexically retained, but also the principal innovations with respect to Latin.

The analysis of other phenomena and the pertinent terminology, which in part can cover the same range of meanings, such as, for example, sopore (sopor), apparenza (apparition) or incubo (incubus), are not dealt with in this essay. Nor will other elements that have been amply documented and have been the subject of a variety of opinions, conjectures, and speculation, such as the quality of dream: whether, for example, a dream is good or bad, i.e. an incubo (a word which, at least in the Italian tradition, finds an ample synonymity in dialect); 5 whether what is seen in sleep is truthful and forewarning or not, as the following saying teaches; 'I sogni non son veri e' pensieri non riescono' (literally, dreams are not true and thought is limited), questions which even Boccaccio treated.

E però, amorose donne, voi dovete sapere che general passione è di ciascuno che vive il veder varie cose nel sonno, le quali quantunque a colui che dorme, dormendo, tutte paian verissime, e desto lui, alcune vere, alcune verisimili e parte fuori d'ogni verità giudichi, nondimeno molte 
esservene avvenute si truovano. Per la qual cosa molti a ciascun sogno tanta fede prestano quanta presterieno a quelle cose le quali vegghiando vedessero, e per li lor sogni stessi s'attristano e s'allegrano secondo che per quegli o temono o sperano; e in contrario son di quegli che niuno ne credono se non poi che nel premostrato pericolo caduti si veggono; de' quali né l'uno né l'altro commendo, per ciò che né sempre son veri né ogni volta falsi. Che essi non sien tutti veri assai volte può ciascun di noi aver conosciuto, e che essi tutti non sien falsi, già di sopra nella novella di Filomena s'è dimostrato e nella mia, come davanti dissi, intendo di dimostrarlo. Per che giudico che nel virtuosamente vivere e operare di niuno contrario sogno a ciò si dee temere né per quello lasciare i buoni proponimenti: nelle cose perverse e malvagie, quantunque $\mathrm{i}$ sogni a quelle paiano favorevoli e con seconde dimostrazioni chi gli vede confortino, niuno se ne vuol credere, e così nel contrario a tutti dar piena fede. (Decameron 4.6.330-331)

(For the fact is, dear ladies, that every living being suffers from the common affliction of seeing various things in his sleep. And although whilst he is asleep they all seem absolutely real, and after waking up he judges some to be real, others possible, and a portion of them totally incredible, nevertheless you will find that many of them come true in the end. This explains why a lot of people have just as much faith in their dreams as they would have in the things they see when they are wide awake, and why their dreams are sufficient of themselves to make them cheerful if they have seen something encouraging, or sorrowful if they have been frightened. At the other extreme there are those who refuse to believe in dreams until they discover that they have fallen into the very predicament of which they are forewarned. In my opinion, neither of these attitudes is commendable, because dreams are neither true every time nor always false. That they are not all true, each of us has frequently had occasion to discover; that they are not all false has been demonstrated a little while ago in Filomena's story, and, as I said earlier, I intend to show it in my own. For I maintain that if one conducts one's life virtuously, there is no reason to be afraid of any dream that encourages one to behave differently or to abandon one's good intentions because of it: and if one harbours perverse and wicked intentions, however much one's dreams appear favorable to these and encourage one to pursue them by presenting auspicious omens, none of them should be believed, whilst full credence should be given to those which predict the opposite.)

Having good and bad dreams is another topic that is amply discussed in treatises on the subject, such as the sixteenth-century work by Gerolamo Cardano, who considers the consequences of certain choices of food:

Se infatti si hanno sogni turbolenti, molto movimentati, vari, oscuri, imperfetti e poco coerenti, diremo allora che provengono dal cibo o dal 
bere. E ciò accade in cinque modi. O perché $\mathrm{i}$ cibi sono quelli che hanno la natura della testa del polipo, del cavolo, della cipolla, dell'ossimele, del coriandolo fresco - come ho detto - e possiamo aggiungere il frutto del giunco, quasi tutte le specie di erba mora, il giusquiamo, la mandragola, il vino, denso e abbondante; insomma tutto ciò che provoca il sonno e genera la bile nera come i legumi e specialmente le fave. Oppure a causa della quantità e della varietà delle cose ingerite, $\mathrm{o}$ a causa dell'ordine sbagliato, quando si mangia molto e cibi di diverso genere, e si mescolano diverse bevande; oppure se a cibo crudo si aggiunge altro cibo; o se il cibo assunto genera disturbi di digestione. (Cardano 32)

(if, in fact, one has turbulent dreams, very animated, varied, obscure, imperfect and incoherent, we will say then that these derive from food or from drink. And this occurs in five ways. Either because the foods have the nature of the head of the polyp, of cabbage, of onions, of ossimele, of fresh coriander — as I said-, and we can add the fruit of the rush, almost all kinds of herbs, henbane, the mandrake, wine which is dense and abundant; in short, all that which induces sleep and generates black bile, such as legumes and especially broad beans. Or because of the quantity and the variety of the things ingested, or because of the wrong order, when one eats a great deal, and foods of different kinds, and one mixes different drinks; or if one adds other food to raw food; or if the food ingested generates problems of digestion.)

The relationship between some nutritive substances, in particular certain foods, and sleeping well and having good dreams, is amply documented; among the foods recommended, there are the following examples taken from documents dating back to the fourteenth century:

Cerano è una petra fata cum'una sagitta imbarbata ... E fa soniare buoni sonii, e no lassa esser morto in batagla. Et è-nne de duo manere e volel-sse portare castamente in cuoro. (Tomasoni 153)

(Cerano is a stone made like a barbed arrow ... And it causes one to have good dreams, and it keeps one from being killed in battle. And it is of two types and one should carry it chastely in leather.)

A provocare il sonno prendasi del suo seme [di lattuga], e si confetti con latte di femmina che nutrica fanciulla femmina e con l'albume d'uovo, e sene faccia impiastro sopra le tempie ... A provocare il sonno facciasi impiastro dell'uno e dell'altro seme [di papavero bianco e nero], o dell'uno col latte della femmina e con l'albume dell'uovo intorno alle tempie .... (Crescenzi 2:291.308)

(To induce sleep take the seed of lettuce, and coat with the milk of a woman who is nursing a female child and with egg white, and apply the poultice to the temples ... To induce sleep make a poultice around the temples of both seeds [black and white poppy seed], or of one of these with the milk of a woman and with egg white ....). 
But the sleep-inducing properties of poppies or lettuce (while leeks or beans produce the contrary effect) are in any case well known; they are also part of the tradition of writings in which culinary practice is combined with information on diet and alimentary hygiene, such as, for example, the fifteenth-century treatise by Bartolomeo Platina. ${ }^{6}$

\section{On the Italian Term sonno (sleep)}

It should be pointed out that in its modern usage the Italian word sonno, a continuation of the Latin somnus (which, as we shall see, meant both 'sleep' and 'dream'), indicates 'a state of repose, sleep, a sleep,' and the 'sensation of physical fatigue, of torpor which induces sleep, or the desire to sleep' etc., used also in expressions such as fare sonno, indurre al sonno, morire di sonno (to sleep, cause to sleep, to be dying to sleep or a sleepy head), ${ }^{7}$ and others. The meanings indicated have been documented for the earliest periods. One can add, moreover, particular designations: sleep as the "personificazione o identificazione con la divinità che presiede al riposo e al sopore, ispiratrice di sogni e visioni notturne"8 (the personification or identification with the divinity which governs rest and sopor, inspiration for dreams and nocturnal visions), as witnessed in literature from Poliziano to Montale; sleep as a designation for death, used more or less in euphemistic expressions such as sonno della morte, eterno sonno, ultimo sonno, ferreo sonno, sonno di pace (sleep of death, eternal sleep, final sleep, inexorable sleep, peaceful sleep), and already present, of course, in ancient literature: "What is sleep but cold death's imitation?" ("Quid est somnus gelidae nisi mortis imago?”) (Ovid, Amores, 2.9.41.40).

In old Italian the word is also equivalent to 'dream,' 'oniric vision,' as attested in various sources from Cavalcanti to Dante to Poliziano. The following examples are taken from Salvatore Battaglia's Grande dizionario della lingua italiana (GDLI):

Disse ka uno die se gia cazanno et adormiose, et in sompno l'aperse deus Mercurius e disseli ke devea avere molie de Grecia (Storie de Troia et de Roma)

(He said that one day he was going hunting and fell asleep, and in a dream the god Mercury appeared to him and told him that he was to take a Greek wife) (History of Troy and Rome)

M'avea mostrato per lo suo forame / più lune già, quand'io feci 'I mal sonno, / che del futuro mi squarciò il velame (Dante, Inferno, 33: 25-28) (He had shown me many moons through its opening, when I had the bad dream that ripped open the veil of the future for me.) 
With regard to the formal aspect, one notices the form sónno with a closed vowel; this example reflects a particular Tuscan treatment of open _o_ (from the short _o_ of Latin) which before _ $n_{\text {_ }}$ appears as closed _o (Rohlfs, 1966, 138). Alongside sónno, one also encounters old variants such as somno, with the consonant cluster fully intact according to the Latin model, and also variants with consonantal epenthesis as in sómpno. The form sóno presents the consonantal degemination typical of northern Italian variants. In the variant suónno, we have a diphthong that is not in the repertory of the Italian literary language but is frequent in southern dialects. ${ }^{9}$ The old Italian plural of sonno presents also the variant sónnora, understood as feminine with the old neutral desinence _ora. It was at one time widely diffused as the plural ending in various Italian dialects ${ }^{10}$ (as well as in the old Italian literary language) ${ }^{11}$ along with sonna, with the ending $\_a$ (originally neutral, then extended to words which approximate a collective concept or signify things understood as inanimate; ${ }^{12}$ below are some documented examples of the variants mentioned: ${ }^{13}$

per far tranquilli i tuoi dubbiosi sonna (Venuti)
(to calm your troubled dreams)
Primo suonno ${ }^{14}$ era (Anonimo romano)
(it was the first phase of sleep)
in quillo mio sompno (Guido delle Colonne volgar.)
(in that dream of mine).

\section{On the Italian Term sogno (dream)}

The word sogno, which etymologically continues the Latin somnium, presents various old Italian variants such as sógnio, sómpnio, sóngnio, sónio, sónnio, with different spellings which render the palatal nasal and the forms it yields. The unusual form suóno with a diphthong is also present (see section above on sonno, also for the quality of the vowel). Old Italian plural forms in the feminine are sógnora and sónna (cf. above for the plural forms of sonno).

The term designates the "attività psichica che si svolge durante il sonno, contraddistinta da emozioni, percezioni, pensieri che prendono forma in sequenze d'immagini" (psychic activity that occurs during sleep, marked by emotions, perceptions, thoughts that take the form of a sequence of images) and also "ciascuna di tali sequenze di immagini" (each of these sequences of images); secondary meanings include "apparenza fallace, illusoria" (false, illusory appearance), "creazione della fantasia che inventa un modo alternativo e diverso, nel bene e nel male, nel presente o 
nel futuro rispetto a quello reale, con cui lo integra o a cui più spesso lo contrappone come ideale da raggiungere" (a creation of the imagination that invents an alternative and different mode, good or bad, present or future, with respect to the real one, with which it blends or, more usually, is set against as an ideal to be reached), "ipotesi fantasiosa" (fanciful hypothesis), "ciò che si desidera fortemente" (that which is strongly desired) etc., as revealed by the GDLI with numerous examples. Among these are the following:

Leggesi di Nabuccodinosor, che fue re che vide sognora che molto lo spaventarono (Giamboni)

(One reads of Nebuchadnezzar, that he was a king who saw dreams that frightened him very much)

e dorme senza sonnia, / ch'è 'n veretate d'onnia, / c'à repusato el core I ne lo divino amore (Iacopone)

(and he sleeps tranquilly without dreams because he possesses all truth since he has rested his heart in divine love)

La nocte sequente el papa vedde in sompnio uno omo povero, in tucto e per tucto multo simile ad sancto Francesco (Vita di san Francesco)

(The following night the Pope saw in a dream a poor man, in every way closely resembling Saint Francis) (Life of Saint Francis)

Bene che moiti suoni siano vannitati, siano moite delusioni de demonia, nientedemeno moiti suoni se trova omo veri como Dio li inspirassi, spezialmente in persone temperate (Anonimo romano)

(Although many dreams are vain, and many are delusions caused by demons, nonetheless one finds that many dreams are true, as though God inspired them, especially in temperate persons)

Apparve in sonnio / il fratel al fratello, in forma e in abito / che s'era dimostrato sul proscenio / nostro più volte a recitar principi (Gabriele Ariosto).

(The brother appeared to his brother in a dream, in the form and in the dress in which he had many times appeared on the stage to recite the role of princes)

\section{On the Italian Term visione (vision)}

The word visione is a learned term which continues the Latin visio, -onis (DEI), literally the action of seeing; it means above all 'to see,' especially seeing a thing in order to examine it, observing something in order to extract information. Among its meanings, however, we also find 'deception,' 'illusion.' Visione is also a visual hallucination, the "percezione di qualcosa che non esiste e pure è ritenuto reale" (Galimberti 32) (perception 
of something that does not exist and yet is held to be real); this meaning usually has a religious or allegorical content.

From the documentation it is clear that the term visione covers a series of phenomena that go from dream to ecstasy. ${ }^{15}$ It overlaps in part with sogno (dream), and it can occur in sleep or in other conditions (while waking or falling asleep), or in other particular states. In old Italian it is sometimes set in opposition to sogno (dream), because it has prophetic qualities and designates a truthful apparition: 16

Pensando di lei, mi sopragiunse uno soave sonno, ne lo qual m’apparve una maravigliosa visione (Dante)

(While thinking of her, a sweet dream overcame me, in which a wondrous vision appeared to me).

A dream (sogno) is usually "dreamt" (or one "has a dream," or one "sees in a dream"), while visions (visioni) are "seen," at times even while sleeping:

Le figliuole vostre propheteranno; \& i vostri vecchi sogneranno i sogni, $\&$ i vostri giovani vedranno le visioni (Marsilio Ficino)

(Your daughters will prophesize; \& your aged will dream dreams, \& your youth will see visions).

Visione is either set in opposition to sogno, or it is differentiated from it. In old Italian usage, visione can be used in place of sogno in order to stress the truthfulness of that which is seen: ${ }^{17}$

disse quello che Talano veduto avea dormendo non essere stato sogno ma visione (Boccaccio, Decameron 9.8)

(he said that what Talano had seen while sleeping was not a dream but a vision)

Questo io non so quello, che possa significare, ne se sia sogno, o visione (Dolce)

(I do not know what this can signifiy, nor whether it be a dream or a vision)

O che visione. Non è sogno, è oracolo: non è fantastico, è profetico (Fiamma)

( $\mathrm{O}$ what a vision. It is not a dream, it is an oracle, it is not imagined, it is prophetic)

Trovandovi piena di grand doglia, / E non mi sofferendo cosa, ond'io / Potessi aver materia di fermarvi / La visione mia, mi stetti cheta, / Temendo, che per sogno non aveste / Quel che vision era (Giraldi. Cinzio) 
(Finding you full of great pain, while I was suffering nothing, for which I could have had grounds to confirm my vision, I remained quiet, fearing that while dreaming you were having a vision)

Quantunque molte volte i sogni de re sieno visioni, non seguita di necessità che sempre sieno visioni (Castelvetro)

(Although many times the dreams of kings are visions, it does not follow of necessity that they are always visions)

Egli imbrogliò talmente tutto ciò che diceva, che diede alla visione tutta la sembianza di un sogno (Francesco Maria Zanotti)

(He mixed up everything he said so much that he gave to the vision all the appearances of a dream)

Ve ne burlate? non avete letto quante volte le disaventure vicine si sono antivedute col mezzo delle visioni, e de' sogni? (Degli Oddi)

(Do you make fun of this? Have you not read how many times imminent misadventures are foreseen by means of visions and of dreams?)

Quivi Paolo ebbe un sogno, e in esso una visione da Dio (Cesari)

(Here Paul had a dream, and in it a vision from God).

Visione can also be synonymous with sogno:

Dice, che fu nell'aurora, per volere mostrare che cotale sogno era significativo del futuro vero, sopra il quale sogno, o vogli visione, egli fonda il suo trattato (Ottimo)

(He says that it occurred at dawn in order to demonstrate that that dream signified the true future, upon which dream, or, if you will, vision, he founds his treatise)

Orsù, pazienza: andiamo Mascheretta, eccovi terminata la mia visione o sogno, o quello che voi lo vogliate dire (Gaspare Gozzi)

(Come now, be still: let's go Mascheretta, here ends my vision or dream, or whatever you wish to call it ).

Visioni (visions) appear during sleep:

Dormendo Apollonio e quel malandrino nel monastero, videro ciascuno una simile visione (Cavalca)

(While sleeping in the monastery, Apollonius and that brigand both had a similar vision)

la visione che apparisce ad Adone mentre dorme (Aprosio)

(the vision that appears to Adonis in his sleep)

Nulla mai visione nel sonno offerse / altrui sì vaghe imagini o sì belle/ come ora questa a lui, la qual gli aperse / i secreti del cielo e delle stelle (Tasso) 
(Never before had a vision offered another during sleep such charming and beautiful images as this one now did to him; it opened to him the secrets of the sky and of the stars)

avendo / vegghiata una gran parte della notte, / alfin lunga stanchezza / recò negli occhi miei placido sonno, / e con quel sonno vision si certa, / che di vegghiar dormendo avrei potuto dire (Guarini)

(having stayed awake for the better part of the night, in the end longstanding fatigue brought placid sleep to my eyes, and with that sleep a vision so true that I could say I was awake while sleeping)

Così adorando, si fue addormentata, / e dal cielo le venne in visione / un angiol, che le diè questa ambasciata (Antonio Pucci)

(while worshipping in this way, she fell asleep, and from heaven an angel came to her in a vision which brought her this message)

Discese il sonno: sorsero nell'alma / le visioni notturne (Cesarotti)

(Sleep descended: nocturnal visions arose in the soul).

A visione is that which is seen in a dream while sleeping:

Pognamo che sia un gran secco, com'egli è ora: e la luna, e le stelle, e gli elementi non sieno secondo natura in tal disposizione, che debbia piovere di qui ad un mese; ma Iddio, che puote tutto ciò, ch'e' vuole, per sua grazia e per gli prieghi d'alcune sante persone, voglia far piovere di qui a tre dì: e ciò riveli in sogno ad una buona persona, non per visione di piova o d'acqua, ma per alcuno contrario, come sarebbe, che quella cotale persona sognasse di ricogliere di terra tre manate di polvere secca, e di gittarle in alti (Passavanti)

(Let us assume that there is a major drought, as there is now: and the moon, the stars, and the elements are, according to nature, in such a configuration that it will not rain for another month; but all powerful and all willing God, through his grace and through the prayers of some holy persons, wishes to make it rain in three days; and this he would reveal in a dream to a good person, not through a vision of rain and water, but through some contrary image, as if that person were to dream of picking up three handfuls of dry dust, and of throwing it high into the air)

Ebbe un sogno, il quale insieme con una visione, che si apparve, viene raccontato da lui stesso, con solenne giuramento (Birago)

(He had a dream, which, together with a vision that appeared, he himself recounted with solemn oath)

Per sogno in visione notturna, quando il sonno viene addosso agli uomini, ed eglino dormono nel letticiuolo loro (Zanobi da Strata)

(Through dream in nocturnal vision, when sleep comes upon men as they lie asleep in their little beds). 


\section{The Latin Terminology and its Romance Derivatives}

We must also consider specifically the Latin words somnus, somnium and visio insofar as they are antecedents of sonno, sogno and visione, in spite of the fact that the scope of somnium and its related terms is very complex and highly developed, as Macrobius, for example, attests: "Aut enim est óneiros secundum Graecos quod Latini somnium vocant, aut est hórama quod visio recte appellatur, aut est chrématismós quod oraculum nuncupatur, aut est enýpnion quod insomnium dicitur, aut est phántasma quod Cicero, quotiens opus hoc nomine fuit, visum vocavit" (Macrobius 1.3.2-3).18 ("There is the enigmatic dream, in Greek oneiros, in Latin somnium; second, there is the prophetic vision, in Greek horama, in Latin visio; third, there is the oracular dream, in Greek chrematismós, in Latin oraculum; fourth, there is the nightmare, in Greek phántasma, which Cicero, when he has occasion to use the word, calls visum.") (87-88). Macrobius thus lists five Latin words that correspond to as many Greek words: somnium, visio, oraculum, insomnium, visum. But, if somnium, visio, visus can be a sign of future developments, in Latin other words are also used, such as divinatio (foreseeing), vaticinatio (foretelling), praesagium (presentiment), prodigium (portent) and others.

Somnus in Latin is also sleep personified and the god of sleep, that is the son of Erebus and Night. Like the Greek hýpnos, it derives from the Indoeuropean root ${ }^{*}$ swep- (noun: swep-no-s, ${ }^{*}$ swop-no-s, ${ }^{*}$ sup-no-s), which designates sleep. Other Indoeuropean languages have terms that reflect notions such as 'to rest,' 'to be lazy,' 'to keep still,' 'the nodding of the head when one is falling asleep' (Buck 268-269). Furthermore, in Indoeuropean languages the word designating sleep can also be used to indicate dream, as in the Slavic languages: Serbian and Croatian san (sleep, dream). In general, 'to sleep' and 'sleep' have parallel signifiers, ones which derive from the same root, as, for example, the Gothic slepan (to sleep) and sleps (sleep). This is not so for Latin, which has dormire and somnus, nor for Greek, which has the verbs katheydō and koimáomai for 'to sleep,' but hýpnos for 'sleep.'

The Latin term somnus, beyond its usual meaning of 'sleep,' is at times used also for 'dream.' Somnus, which signifies both 'sleep' and 'dream,' has a Pan-Romance development: Italian sonno, Provençal som, old French somme (later substituted by sommeil from Latin somniculus, which is not attested by any text, but figures in the Tironian notes), Catalan son, Spanish sueño, Portuguese somno, Roumanian somn, Dalmatian samno, etc. ${ }^{19}$ In the Italian dialects, especially the Southern ones, sonno maintains its meaning sogno (dream) (AIS). The Sardinian sonnu, used in Cagliari and 
among the bourgeoisie of the towns with the meaning sogno (dream), is probably not a continuation of the Latin somnus but rather an imitation of the Italian sonno (sleep), which in Southern areas means both sonno and sogno (sleep and dream), given the isolation of the word, and the fact that in Sardinian dream is bisu. ${ }^{20}$

A Latin derivative of somnus, of which it represents an extension, is somnium (It. sogno; dream), found also as sonno (sleep) (in Silius Italicus). The word is a Western Pan-Romance continuation (it is in fact absent in Roumanian): Italian sogno; Western Ladino sömni, semmi; French songe, Spanish sueño; Portuguese sonho (REW). In Gallo-Romance dialects songe and its variants mean "sleep" (hence the phrases faire un songe, 'to sleep,' faire un soin, 'to siesta'), which reflects the secondary meaning of the Latin somnium (FEW).

From the comparison of the Romance forms thus far considered, it is clear that in Spanish the term sueño corresponds to both 'sleep' and 'dream.' This is because the Latin cluster _mn_, assimilating to _nn_, is then modified to _ $\tilde{n}_{-}$(cf. other words such as domnu > dueño, autumnu > otono). In the same way, the cluster_mni_(like _nni_) gives _ $\tilde{n}_{-}$; thus, through a process of analogous phonetic evolution, the Latin words somnus and somnium give the same result, sueño, which covers both meanings, 'sleep' and 'dream' (García De Diego 121). One cannot, however, completely exclude the fact that this may be a matter of the continuation of one of the two Latin roots, considering that both Latin meanings are represented also in the old Italian sonno (sleep).

As for the Latin visio, _onis ? 'seeing', 'vision (abstract and concrete),' also 'point of view' (Greek theōría) ? it is a rare term pertaining to philosophical language, without a doubt created in order to translate the Greek phantasía and phántasma (Ernout and Meillet 733). Its Romance derivatives, like the Italian visione or the French vision, are in general learned terms (DEI). The Portuguese terms avejāo, vejāo, visão are considered popular continuations: "phantasma; entitade que se figura á imaginação popular; coisa sobrenatural, que se vê em espirito ou se suppóe ver pelos olhos; supposta imagem que se julga ver por sonho; ecc." 21 (phantasm; an entity of the popular imagination; supernatural being, manifested as a spirit or which supposedly can be apprehended by sight; an image supposedly seen in dreams; etc.) Instead, the Sardinian visione, bisione22 (It. sogno [dream]), with the verb visionare, visionài (It. sognare [to dream]) —heard in certain localities-is not of purely popular derivation. According to the DES, it cannot directly reflect the Latin visiogiven that_si_becomes_ST_ in native words; it is, therefore, to be considered a learned word mediated by Italian. 
The Roumanian vis (dream) (see Cioranescu 898), which derives from the Latin visum (vision, apparition in the concrete sense, dream), represents a continuation from Latin sources different from the ones mentioned thus far. In philosophical language it is a translation of the Greek phantasía (Ernout and Meillet 733). As already mentioned, in Roumania the Latin somnium does not continue.

The same Latin root visum is the origin of the Sardinian bis'u, vis'u (with the article $s u i s^{\prime} u$, and the weakening and disappearance of the consonant in phonosyntactic position) and the verb vis'are, vis'ai (to dream) expressed also by the phrase fai bis'us.

Another signifier illustrating the preservation of the Latin is the Spanish ensueño (dream). It exists together with the above-mentioned sueño, and serves to break up the homonymy of sueño (sleep, dream). Ensueño continues the Latin insomnium (dream), formed from somnium as a calque of the Greek enoyppnion (dream) in order to obtain a word of a higher register compared to somnium, which was lowered through popular usage. The first example is in Virgil (Aeneid 4.9), and in prose it is not documented before Tacitus (Ibid., 635). In Latin insomnium has a rare, literary usage, but it is continued in the Romance languages not only by the Spanish ensueño but also by the Italian insogno (dream, vision) with variants like insonio, insonnio. It is a word of low register and more or less obsolete (although widely present in the dialects of northern and central Italy), even in contrast to sogno (dream), as the following passage illustrates: "Dovete intendere ancora che il sogno e lo insogno non è tutto uno, però che il sogno significa le cose future, che lo insogno quelle che sono presenti" (Gabriello Simeoni [GDLI]) (You should also understand that sogno and insogno are not one and the same, because sogno signifies future things, and insogno present ones.)

\section{Romance Lexical Innovations}

As far as the concepts being considered here are concerned, in particular those connected to sonno (sleep) and sogno (dream), the lexical innovations with respect to the Latin tradition offer numerous materials, traceable through lexicographical repertories and linguistic atlases, which increase when we dwell also on nuances of meaning relative to such aspects as the quality of sleep, the first phase of sleep etc. It will be sufficient to observe the data for Sardinian reported in the DES for the concept 'sleep.' Besides sonnu, other words such as the following also exist: ciribecca, used to refer rather to drowsiness (of uncertain etymology); mas'edu (literally 'tame,' 'domesticated' from the proper name Mansueto); pintsighe (prevalent in 
the northern Logudorese variety) with the verb pintsulare 'to doze,' 'to drowse,' 'to nod' (to be compared to the Corsican pinciulà 'to nod one's head from drowsiness'; in Italian penzolare); surtu, sustu, which, besides 'sleep,' refer to the parts into which sleep can be divided (thus a sleep can be a unu surtu, or in duos or in tres surtos according to fatigue or mental state, and is connected to the idea of a sudden awakening; etymologically it appears to derive from the Catalan (en)surt (start, jump). Briefly, onomaturgy produces various results, even playful forms such as words of the following type found in Calabrese dialect to designate sleep: zusaveru or zupàgulu or zupeppe, personifications corresponding respectively to "zio Saverio, Paolo, Peppe" (Rohlfs 1977, s.v.) (uncle Saverius, Paul, Joe).

One of the most significant Romance innovations in the designations for dream is certainly the French rêve, as well as the variation rêverie, derived from the verb rêver (to dream). The etymological history of this lexical family is rather complex and has been interpreted in different ways. Rêver, attested as early as the twelfth century, equals 'to wander,' 'roam' until the fifteenth century, and 'to rave' until the eighteenth century; the modern sense appears clearly around 1670. Rêverie, documented around 1200 (whereas rêve is attested only later, in 1680), still stood for 'delirium' in the seventeenth century, but had its present meaning in Montaigne. A first etymology, proposed by Friedrich Diez (370), links these terms to the spoken Latin *rabia, derived from the classical Latin rabies, but this hypothesis lacks credit. One must also think of the derivatives of vagus (wandering), vagare (to wander), such as ${ }^{*}$ re-ex-vagare, or rather of the Latin evadere (to escape), with the derivative re-exvadare (Schalk 9-38; Guiraud, s.v.).

\section{Onomasiological and Semasiological Aspects}

As far as the onomasiological aspect goes, the Romance terms that express the notions of sleep, dream, and vision are derivatives of Latin words (somnus, somnium and insomnium, visio). They are generally widespread, but some words are limited to specific areas (for example, visum, which continues in peripheral areas of Romance Europe such as Roumania and Sardinia). We have seen, moreover, that derivatives of somnus can designate both sonno (sleep) and sogno (dream). The same is true for the derivatives of somnium, as had occurred in Latin itself; thus it is not necessary to presuppose any metaphorical meanings. In Latin, somnus, besides indicating 'sleep,' is also the god of sleep and of somnium (dream), and hence somnium itself.

Among the developments of a semasiological order-namely, the different meanings that a word can assume-one should at least recall that in 
various southern Italian dialects the lexeme sonno (sleep) means at the same time sonno and sogno (sleep, dream); but it is also the name corresponding to 'temple' (the region of the side of the head), considered to be the seat of sleep. 23 Sonno in the sense of 'sleep' and 'temple' is found in some of the dialects of Emilia, of the Veneto, and in certain limited areas of Piemonte (Cuneo, according to geolinguistic sources). ${ }^{24}$ But in the latter, the dialectical form is sogn, i.e. a derivative of the Latin somnium, which, etymologically, reunites the two meanings 'dream' and 'sleep' (by contrast, in other areas it is the forms yielded by somnus that signify sleep and dream), with an interesting re-determination of gender: the masculine form of sogn signifies concrete concepts, i.e. 'dream' and 'temple,' while the feminine form signifies the abstract concept 'sleep.'25

The onomasiological reason for the above rests on the belief that the temple is the seat of sleep. This is confirmed, for example, by the fact that in the Italian dialects of the region of Emilia, the temple is called dormitore (cf. AIS, ALI). This is not an isolated case; in Latin itself, sopor-that which makes one fall asleep, sleep deified-also signifies the temples (Ernout and Meillet 635). This word is used mainly in a poetic sense, and this learned usage continues in the Romance languages. Other languages, even non-Indoeuropean ones, use the word meaning 'sleep' to indicate the temples. For example, in German Schläfe (temples), is the plural of Schlaf (sleep); in Basque lu, lo mean both 'sleep' and 'temple' (Frisk 20). The relationship between sleep and the temples recalls the representation of the Greek god Hypnos, a youth who walks with a light step and who has wings sprouting out of his temples. ${ }^{26}$ Moreover, certain ointments used to induce sleep are spread on the temples. As Crescenzi prescribes (see above), the preparation is made with poppy seed: "A provocare il sonno facciasi impiastro dell'uno e dell'altro seme [di papavero bianco e nero], o dell'uno col latte della femmina e con albume dell'uovo intorno alle tempie" (2.308) (to induce sleep make a poultice around the temples of both seeds [black and white poppy], or of one of those with the milk of a woman and with egg white or with lettuce). ${ }^{27}$ And Annibal Caro adds: "Il Sonno allora di leteo liquore / e di stigio veleno un ramo asperso / sovra gli scosse [a Palinuro] e l'una tempia e l'altra / gli spruzzò sì, che gli occhi ancor rubelli / gli strinse, gli gravò, gli chiuse alfine" (GDLI s.v. sonno). (Sleep then shook a branch besprinkled with lethean liquour and stygian poison over him [Palinurus], and he sprinkled one and the other temple, so that he pressed, weighed down, and finally closed his still rebellious eyes.)

Finally, remaining within the history of culture as it is reflected through language, one point has still to be made on the interesting ono- 
masiological relationship that exists between enrêve (a dialectical variety of the French reve) and the same name given to the yarrow in certain regions of France: the plant is so called in those areas because youths would place its leaves over their eyes before going to sleep in order to have sweet dreams. For the Romans (Beccaria, 98), the same plant symbolized sleep: many sarcophagi, the custodians of eternal sleep, are adorned with it.

\section{Università degli Studi di Udine}

Translated from Italian by Mario D'Alessandro

\section{NOTES}

${ }^{1}$ According to legend, Sleep allowed Endymion to sleep with his eyes open so that he could always see his beloved Selene; cf. in Italian dormire ad occhi aperti (literally, to sleep with one's eyes open or, in other words, to be dead tired).

${ }^{2}$ Galimberti, s.v. writes that "il termine investe un campo di significati che riguardano: 1) il funzionamento della facoltà visiva; 2) la percezione visiva, dove le informazioni raccolte dall'organo di senso vengono organizzate in campi e oggetti dotati di significato; 3) l'allucinazione che è una falsa percezione, involontaria e non criticata, che ha i caratteri della sensorialità e della proiezione spaziale; 4) l'illusione che è una distorsione della percezione dove stimoli sensoriali esterni si combinano con elementi riprodotti; 5) la visione del mondo che è il modo di concepire la realtà; 6) la visione nell'accezione religiosa di visione soprannaturale, profetica, mistica; 7) la visione extrasensoriale che è una percezione senza l'intervento della facoltà visiva. La polivalenza del termine dipende dall'ambiguità intrinseca allo statuto della visione a cui compete, oltre alla facoltà di osservare, verificare e constatare, anche l'incognita dell'inganno, dell'illusione della falsa percezione." (the term includes a range of meanings that concern: 1) the workings of the visual faculty; 2) visual perception, in which the information collected by the sense organ is organized into fields and objects endowed with meaning; 3) hallucination, which is a false perception, involuntary and uncriticized, which has sensory characteristics as well as characteristics of spatial projection; 4) illusion, which is a distortion of perception in which external sensorial stimuli are combined with reproduced elements; 5) a view of the world, which is the way of conceiving reality; 6) vision in the religious sense, which is a supernatural, prophetic, mystic vision; 7) extrasensory vision, which is perception without the intervention of the visual faculty. The polyvalence of the term depends on the intrinsic ambiguity of the vision to which it belongs, besides the faculty of observing and verifying the unknown connected with the deception or the illusion of false perception.)

${ }^{3}$ Lessico universale italiano (LUI).

${ }^{4}$ On the Romance languages see the dictionaries by Wartburg (referred to as FEW), Battisti and Alessio (DEI), Coelho, De Moraes Silva, García De Diego, and Cioranescu. 
${ }^{5}$ Cf. the study by Cappello.

6Platina writes as follows: "[La lattuga] è un alimento che concilia il sonno" (86) ([lettuce] is a food that brings on sleep); "il papavero ... quello nero concilia il sonno" (71) (the black poppy ... brings on sleep); "L'uso eccessivo del porro provoca tuttavia mal di testa e insonnia" (70) (Excessive use of leeks causes headaches and insomnia ); "[La fava] in qualsiasi modo la si mangi, il suo uso provoca insonia" (148) (No matter how they are eaten, [broad beans] cause insomnia). Similar information can be found in the seventeenth-century treatise by Pisanelli: "[la fava] fa venire sogni pieni di travaglio, e di perturbazione" (71) ([broad beans cause dreams full of anguish and perturbation); "[la lattuca] leva le vigilie" (41) ([lettuce] removes sleeplessness).

${ }^{7}$ The expression 'morto di sonno' (dying to sleep or dead tired), said of one who has a great desire to sleep, is also used, with ironic intent, as an injurious epithet for a person who is indolent and without vitality or will.

${ }^{8}$ Battaglia (referred to henceforth as GDLI), s.v.

9'ho sonno' (I am sleepy). Cf. Sprach- und Sachatlas Italiens und der Siidschweiz (henceforth referred to as AIS), 4.1.643.

${ }^{10} \mathrm{Cf}$. the Sicilian forms 'li sónnira' (the temples) (sing. 'lu sónnu'); in San Biagio Platani, 'i suónnira' (sing. 'u suónnu'), in Catenanuova (AIS 100) formally corresponding to 'i sonni' ( $\mathrm{cf}$. below for sonno in the sense of 'temple').

${ }^{11}$ Rohlfs $1966,39$.

12Ibid., 36.

${ }^{13}$ The attestations are taken from GDLI.

${ }^{14}$ The 'primo sonno' is "la prima fase del riposo notturno molto leggero, tanto che da alcuni è considerato di transizione con la veglia" (GDLI) (the first, very light, phase of nocturnal sleep, so much so that some consider it to be a phase of transition with wakefulness, particularly in the expression 'nel' or 'sul primo sonno' [right after falling asleep]).

${ }^{15}$ In modern common usage, the term often has a negative connotation; the expression 'sono visioni!' (they are only visions!) suggests that one is daydreaming.

${ }^{16} \mathrm{Cf}$. also Schmitt 13 and passim. Unless otherwise specified, the citations that follow are taken from GDLI.

${ }^{17}$ Unless otherwise indicated, the references are from GDLI.

${ }^{18}$ Cited in Schalk 5.

${ }^{19}$ Meyer-Lübke (henceforth referred to as REW), s.v.

${ }^{20}$ Wagner (henceforth referred to as DES), s.v.

${ }^{21} \mathrm{Cf}$. Coelho and De Moraes Silva. Thanks go to Professor Josiah Blackmore for the translation of this passage.

${ }^{22}$ The voiced dental fricative is transcribed with _s'_.

${ }^{23}$ Cf. Marcato; Cortelazzo and Marcato 408.

${ }^{24}$ Atlante Linguistico Italiano (henceforth ALI), No. 18 and AIS, No. 100. 
${ }^{25}$ The same development is also found in other northern varieties, e.g. in Feltre in the Veneto region. Elsewhere, as in Friulian, the differentiation of gender does not imply the meaning 'temple' (which is designated by another lexeme), but only sleep (in the feminine) and dream (in the masculine); cf. Marcato. In the latter variety, the word sium, literally 'sleep', is feminine when it refers to 'sonno,' 'bisogno di dormire' (sleep, the need to sleep) but masculine for "sonno, fatto fisico oggettivo," "sogno" [sleep, the objective physical fact, dream] (cf. Pirona et al.).

${ }^{26} \mathrm{Cf}$. "Hypnos," in Enciclopedia dell'arte antica, 4.62-63.

27 The poultice with lettuce is mentioned above in the introduction to this paper.

\section{WORKS CITED}

Atlante Linguistico Italiano. Rome: Istituto Poligrafico e Zecca dello Stato, 1995(ALI).

Battaglia, Salvatore. Grande dizionario della lingua italiana. Turin: UTET, 1961(GDLI).

Battisti, Carlo and Giovanni Alessio. Dizionario etimologico italiano. Florence: Barbera, 1950-1957 (DEI).

Beccaria, Gian Luigi. I nomi del mondo. Turin: Einaudi, 1995.

Boccaccio, Giovanni. Decameron. Trans. George Henry McWilliams. London: Penguin Books, 1972.

Buck, Carl Darling. A Dictionary of Selected Synonyms in the Principal Indocuropean Languages. Chicago-London: University of Chicago Press, 1949; rpt. 1965.

Cappello, Teresa. Le denominazioni italiane dell' 'incubo.' Padua: Soc. Coop. Tipogr., 1957.

Cardano, Gerolamo. Sul sonno e sul sognare. Eds Mauro Mancia and Agnese Grieco, 2nd. ed. Venice: Marsilio, 1992.

Ciccarese, Maria Pia (ed). Visioni dell'aldilà in occidente. Fonti modelli, testi. Florence: Nardini-Centro internazionale del libro, 1987.

Cioranescu, Alejandro. Diccionario etimologico mano. Tenerife: Biblioteca Filologica, 1966.

Coelho, Adolpho. Diccionario manual etymologico da lingua portuguesa. Lisbon: Plantier Editor, n.d.

Cortelazzo, Manlio and Carla Marcato. I dialetti italiani. Dizionario etimologico. Turin: UTET, 1998.

Crescenzi, Piero de'. Trattato della agricoltura, traslatato nella favella fiorentina rivisto dallo 'Nferigno accademico della Crusca, ridotto a migliore lezione da Bartolomeo Sorio. Verona: Vicentini e Franchini, 1851.

De Moraes Silva, Antonio. Diccionario da lingua portugueza. Lisbon: Antonio José da Rocha, 1858.

Diez, Friedrich. An Etymological Dictionary of the Romance Languages. Trans. T. C. Donkin. London: Williams and Norgate, 1864.

Enciclopedia dell'arte antica. Rome: Istituto dell'Enciclopedia Italiana, 1961. 
Ernout, Alfred and Antoine Meillet. Dictionnaire étymologique de la langue latine. Histoire des mots, 4th ed. Paris: Klincksieck, 1959.

Frisk, Hjalmar. Quelques noms de la tempe en indo-européen. Göteborg: Wettergren \& Kerbers Förlag, 1965.

Galimberti, Umberto. Dizionario di psicologia. Turin: UTET, 1992.

García De Diego, Vicente. Gramática histórica española. Madrid: Gredos, 1970.

Guiraud, Pierre. Dictionaire des étymologies obscures. Paris: Payot, 1982.

Lessico universale italiano. Rome: Istituto dell'Enciclopedia Italiana, 1968- (LUI). Macrobius, Commentary on the Dream of Scipio. Trans. William Harris Stahl. New York: Columbia University Press, 1952.

Marcato, Carla. "Sul tipo lessicale 'sonno' come designazione della 'tempia' nell'italoromanzo," Studi mediolatini e volgari 43 (1997): 193-202.

Meyer-Lübke, Wilhelm. Romanisches etymologisches Wörterbuch. Heidelberg: Winter, 1935 (REW).

Ovid. The Love Poems. Trans. A.D. Melville. Oxford: Oxford University Press, 1990.

Pirona, Giulio Andrea et al. Il Nuovo Pirona. Vocabolario friulano. Udine: Società Filologica Friulana, 1935.

Pisanelli, Baldassarre. Trattato della natura de' cibi et del bere (Venice: Imbrighi, 1611); anastatic rpt. Bologna: Forni, 1980.

Platina, Bartolomeo. Il piacere onesto e la buona salute. Ed. Emilio Faccioli. Turin: Einaudi, 1985.

Rohlfs, Gerhard. Grammatica storica della lingua italiana e dei suoi dialetti. Fonetica. Turin: Einaudi, 1966.

- Nuovo dizionario dialettale della Calabria (con repertorio italo-calabro). Ravenna: Longo, 1977.

Schalk, Fritz. Somnium und verwandte Wörter in den romanischen Sprachen. Cologne and Opladen: Westdeutscher Verlag, 1955.

Schmitt, Jean Claude. Spiriti e fantasmi nella società medievale. Rome-Bari: Laterza, 1995.

Sprach-und Sachatlas Italiens und der Südschweiz. Eds. K. Jaberg and J. Jud, 8 vols. Zofingen, Switzerland: Ringier \& Co., 1928-40 (AIS).

Tomasoni, Piera. "Il 'lapidario estense'," Studi di filologia italiana 34 (1976): 131186.

Wagner, Max Leopold. Dizionario etimologico sardo. Heidelberg: Winter, 19601964 (DES).

Wartburg, Walther von. Französisches etymologisches Wörtebuch. Bonn-LeipzigTübingen-Basel: J.C.B. Mohr, 1922 (FEW). 